\title{
СУЧАСНІ ПІДХОДИ ДО ДІАГНОСТИКИ ТА ЛІКУВАННЯ ЗЛОЯКІСНИХ ЗАХВОРЮВАНЬ
}

\section{Науково-практична конференція (для молодих вчених)}

\author{
22 березня 2019 р. \\ Київ
}

DOI: 10.32471/clinicaloncology.2663-466X.38.22424

\section{Гістологічні типи пухлин жирової тканини та їх характеристика \\ Л.С. Болгва, О.І. Алексєєнко, А.О. Пономаренко Національний інститут раку, Киів, Украӥна}

Bcmyn. Показники особливостей структури пухлин м'яких тканин (ПМТ) наразі не представлені в Національному канцер-реєстрі України. Зважаючи на це, подаємо характеристику одних з найбільш поширених новоутворень м'яких тканин жирової тканини.

Meта: визначити гістологічні типи новоутворень жирової тканини (НЖТ) і провести їх багатофакторний аналіз.

Об'єкт і методи. Вивчено статистичний матеріал 3574 хворих з ПМТ, з них - 503 з НЖТ, які обстежувалися і лікувалися в Національному інституті раку з 2009 по 2018 р. Проведено ретроспективне дослідження гістологічних типів НЖТ, діагностованих цитологічним та гістологічним методами, у пацієнтів чоловічої і жіночої статі у віковому аспекті.

Результати. Хворих з НЖТ було $503(14,1 \%)$ в групі ПМТ. Визначено, що НЖТ часто виникали у жінок $356(70,7 \%)$ випадків. Найбільша кількість пацієнтів була у віковому інтервалі після 60 років - $233(46,3 \%)$.

При дослідженні НЖТ виявлено 190 (37,8\%) їх злоякісних форм - ліпосарком. При цьому відмічено різні морфологічні підтипи у $17(3,4 \%)$ хворих: міксоїдна - у $8(1,6 \%)$, високодиференційована $-4(0,8 \%)$, плеоморфна $-2(0,4 \%)$, дедиференційована $-2(0,4 \%)$ і ембріональна ліпосаркоми $-1(0,2 \%)$.

Більшість НЖТ становили доброякісні пухлини у 311 (61,8\%) пацієнтів. Серед них у $178(57,2 \%)$ встановлено ліпоми i у $133(42,8 \%)$ - ліпоми з різними компонентами мезенхімних тканин: фіброліпома - у 65 (20,9\%), ангіоміоліпома - 47 (15,1\%), ангіоліпома $-20(6,5 \%)$ та ліполейоміома $-1(0,3 \%)$ хворих.

Крім того, у $2(0,4 \%)$ пацієнтів виявлено непухлинні захворювання жирової тканини.

Висновки. Таким чином, визначено гістологічні типи 503 НЖТ, серед яких переважали доброякісні процеси у $313(62,2 \%)$ хворих. При цьому в $133(42,8 \%)$ випадках вони мали багатокомпонентну гістологічну структуру, що обгрунтовує їх назву - мезенхімальні. Ліпосаркоми діагностовано у $190(37,8 \%)$ пацієнтів. Відмічено, що частіше доброякісні і злоякісні НЖТ розвиваються у жінок віком старше 60 років.

\section{Хірургія печінки при метастатичному колоректальному раку: зняття обмежень}

\section{А.А. Бурлака, А.А. Шудрак, О.О. Колеснік \\ Національний інститут раку, Київ, Україна}

Bcmyn. Ефект ішемії-реперфузії (I/P) в печінці найчастіше виникає при виконанні великих та розширених резекцій печінки, зокрема при оклюзії притоку крові маневром Прінгла (МП), тотальній оклюзії притоку та відтоку. Навіть за відсутності оклюзії портального притоку крові оксигенація печінки значно знижується під час мобілізації/ретракції органа та його підготовки до транссекції паренхіми, що призводить до додаткового пошкодження та загибелі гепатоцитів. Печінка з фіброзом, стеатозом в умовах токсичного пошкодження хіміотерапією є більш чутливою до пошкоджувального впливу I/P. На тваринних моделях доведено, що пошкодження внаслідок МП та I/Р під час резекції печінки призводить до дисфункції гепатоцитів, підвищення рівня прозапальних цитокінів та матриксних металопротеїназ в оперованій печінці, в подальшому може стимулювати прогресування мікрометастазів карциноми метастатичного колоректального раку (мКРР).

Об'єкт і методи. Дослідження передбачало проведення ретроспективного аналізу впливу методології виконання резекцій печінки на прогноз виживаності хворих мКРР. Проводився аналіз клінічних даних за останні 10 років 3 архіву історій хвороби та канцер-реєстру на базі Національного інституту раку.

Результати. Медіана виживаності хворих становила

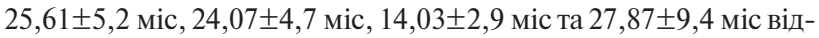
повідно для груп А (IOП+), В (IOП-), В (IOП+) та А (IOП-) $(\mathrm{p}=0,03)$. Таким чином, хворі на мКРР, оперовані із застосуванням МП та з ішемією оперованої печінки в післяопераційний період, мали достовірно найгірший онкологічний прогноз.

Висновки. Отримані власні результати свідчать про негативний вплив застосування МП на виживаність хворих на мКРР. Ішемія оперованої печінки може бути новим фактором онкологічного прогнозу та індикатором якості хірургічного лікування. Вважаємо за необхідне проаналізувати групу хворих на мКРР, що були оперовані із застосуванням модифікованого МП, а також вивчити проблему впливу патологічного ефекту I/P на ініціацію пухлинного росту в умовах рандомізованого дослідження.

Рідкісний випадок муцинозної карциноми волосистої частини голови у практиці лікаря отоларинголога-онколога

Н.С. Вавілон, О.М. Дідич, Ю.Г. Карпенко

Хмельницький обласний онкологічний диспансер, Україна

Bcmyn. Онкологічні захворювання $€$ актуальною проблемою всього людства. Існує певна настороженість лікарів щодо найбільш поширених онкозахворювань, тоді як рідкісні пухлини створюють суттєві труднощі для діагностики та лікування.

Муцинозна екринна карцинома - вкрай рідкісна злоякісна пухлина шкіри, яка виникає з потових залоз. У медичній літературі описано менше 150 випадків цієї патології.

Поширеність: у 2 рази частіше виявляють у чоловіків, вік виникнення - від 50 до 70 років. Найчастіше пухлини виникають на повіках (41\%), у решті випадків - на шкірі голови (17\%), обличчі (14\%), у пахвових западинах (9\%), на грудях/животі (7\%), зовнішніх статевих органах (4\%), шиї (2\%), кінцівках (2\%), у кутах очної щілини (2\%), пахової ділянки (1\%) і на вухах (1\%). 
Мета дослідження. Підвищити точність діагностики та лікування такого рідкісного захворювання, як муцинозна карцинома.

Об'єкт і методи. Окрім імунного фарбування для підтвердження пухлинного походження, гістологічні ознаки можуть допомогти в диференціації між основними та метастатичними карциномами молочної залози, шлунково-кишкового тракту, яєчника, легені. Первинні ураження, як правило, мають більш організовані епітеліальні клітини, на відміну від метастатичних клітин. Зазвичай пухлина проявляється у вигляді солітарного вузла діаметром 0,5-3 см з гладкою поверхнею, кольору шкіри або злегка блакитного відтінку, щільно-еластичної консистенції, інколи із виразкуванням. Скупчення клітин містяться в «озерах» муцину, розділених тонкими перетинками. Ступінь клітинної атипії може бути різноманітним. Пухлинні клітини можуть формувати залозисті та протокоподібні структури у вигляді комплексів солідного, криброзного, аденокістозного і папілярного типу. По периферії можуть розміщуватися клітини з апокринним типом секреції.

Результати. Хвороба має відносно хороший прогноз, метастазує рідко, але частота рецидивів висока - понад $29 \%$. Низький метастатичний потенціал пов'язаний з аваскулярною характеристикою пухлини. Незважаючи на це, пухлина стійка до хіміо- та променевої терапії, тому методом вибору при лікуванні залишається висічення з відступом від країв близько 1 см, оскільки існує високий ризик рецидиву.

У своїй практиці ми спостерігали один випадок муцинозної карциноми

Хвора Г. 1949 р.н. звернулася в поліклініку Хмельницького обласного онкологічного диспансеру зі скаргами на наявність пухлини на шкірі волосистої частини голови. 3 анамнезу стало відомо, що новоутворення наявне багато років, з неухильним повільним ростом. Об'єктивно: на тім'яно-потиличній ділянці справа щільно-еластичне солітарне новоутворення, рухоме, 3 флуктуацією, діаметром 4,0 cм, кольору шкіри, з поверхневим виразкуванням.

Хворій виконано оперативне втручання в обсязі радикального висічення новоутворення. Отримано патогістологічний висновок - муцинозний рак, для виключення вірогідності метастазу необхідне клінічне дообстеження з метою виявлення первинного вогнища. Проведено рентгенологічне обстеження органів грудної порожнини, ультразвукове дослідження органів черевної порожнини, нирок, слинних залоз, мамографію, езофагогастродуоденоскопію. Враховуючи відсутність даних про первинне вогнище, пухлину волосистої частини голови розцінено як первинну. Хвора отримала ад'ювантний курс поліхіміотерапії за схемою: доксорубіцин 100 мг, цисплатин 100 мг та післяопераційний курс близькофокусної рентгенотерапії на ложе пухлини і ділянку післяопераційного рубця сумарною вогнищевою дозою 64 Гр. Під час контрольного огляду через 1 та 3 міс ознак рецидиву пухлини не виявлено.

Висновки. Муцинозна екринна карцинома - рідкісна первинна карцинома потових залоз із низьким ступенем злоякісності, що потребує настороженості лікарів щодо іiї діагностики та лікування.

\section{КT та MPT для виявлення та диференційної діагностики мас та вузлів межистіння \\ О.В. Горошенко \\ Український центр томотерапії, Кропивницький, Україна}

Медіастинальні маси та вузли часто зустрічаються як у пацієнтів із відомою онкологічною патологією, так і як випадкові знахідки при обстеженні органів грудної порожнини. В еру широкого використання комп'ютерної томографії (КТ) такі виявлення почастішали, що створило проблему алгоритму диференційної діагностики цих мас для визначення правильної тактики лікування чи спостереження, уникнення невиправданих інтервенцій.
Mema: ознайомити колег із підходами до виявлення та оцінки вузлів/мас межистіння, використання КТ та магнітно-резонансної томографії (МРТ) для їх виявлення, спостереження, диференційної діагностики.

Висновки. КТ та МРТ дозволяють впевнено виявляти, оцінювати медіастинальні вузли та маси. Найбільшу цінність для вирішення цих завдань має МРТ за рахунок високої м'якотканинної роздільної здатності, можливості виявлення дрібних включень жирової тканини. Однак потенціал діагностичних зображень поки лишається обмеженим; у таких ситуаціях для вирішення діагностичних питань варто використовувати інтервенцію для морфологічної верифікації вузлів/мас.

\section{Агресивний фіброматоз: тактика "wait and see» з оцінкою прогностичних факторів прогресії захворювання}

\section{С.А. Дєдков, М.М. Кукушкіна, С.І. Коровін, В.В. Остафійчук, Д.А. Чорненький}

Національний інститут раку, Київ, Україна

Bcmyn. Агресивний фіброматоз (АФ) - рідкісна мезенхімальна пухлина м'яких тканин з агресивним перебігом, але без метастатичного потенціалу. Згідно з опублікованими даними частота рецидивів після хірургічного видалення коливається від 30 до 40\%. 3 іншого боку, відомо, що АФ схильний до самовільної стабілізації та спонтанної регресії. Таким чином, для деяких груп пацієнтів може використовуватися тактика активного спостереження. Дані про фактори прогнозу прогресії захворювання суперечливі.

Mema: пошук прогностичних факторів, пов'язаних з прогресуванням захворювання у пацієнтів з АФ, які перебувають під активним спостереженням.

Об'єкт і методи. У дослідження було включено 35 пацієнтів 3 гістологічно верифікованим АФ: 19 (54,2\%) - 3 первинною пухлиною, $16(45,8 \%)-3$ рецидивом АФ; середній вік - 34,2 $\pm 13,5$ року; $20(57,1 \%)$ чоловіків, $15(42,9 \%)$ жінок; локалізація на тулубі - 22 (62,9\%), на кінцівках - $13(37,1 \%)$;

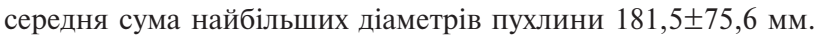
Для всіх пацієнтів використовувалася тактика активного спостереження. Протягом періоду спостереження прогресування захворювання відмічали у 11 (31,4\%) пацієнтів, у 24 (68,6\%) стабілізацію. Досліджено такі чинники, як вік, стать, локалізація та розмір пухлини, попереднє лікування, як предиктори прогресії захворювання.

Результати. В однофакторному аналізі старший вік $(37,2 \pm 19,1$ року проти $32,8 \pm 10,1$ року; $p=0,943)$ і менша сума діаметрів пухлини (176,5 $\pm 71,6$ мм проти $183,8 \pm 78,8$ мм; $\mathrm{p}=0,859)$ пов'язані з прогресією захворювання. Жіноча стать (жіноча/чоловіча: OR 1,48; 95\% CI 0,28-8,75; p=0,599), відсутність попереднього лікування (первинна пухлина/рецидив пухлини: OR 1,$75 ; 95 \%$ CI 0,33-10,3; p=0,452), локалізація на тулубі (тулуб/кінцівки: OR 1,67; 95\% СI 0,30-8,97; $\mathrm{p}=0,491$ ) були несприятливими прогностичними факторами.

Висновки. Жіноча стать, вік старше 27 років, відсутність попереднього лікування і локалізація пухлини на кінцівках асоційовані з несприятливим прогнозом, проте їх вплив на прогресію захворювання у пацієнтів з АФ статистично недостовірний.

\section{Варіанти анастомозів при лапароскопічних резекціях шлунка \\ о.Л. Добринський}

Українська медична стоматологічна академія, Полтава, Україна

Bcmyn. За даними Національного канцер-реєстру України, рак шлунка займає чільне місце серед онкологічних захворювань. Одним із провідних методів лікування є хірургічний. 3 метою зменшення післяопераційних ускладнень, зниження оперативної травматизації, кращої візуалізації структур та більш делікатної роботи з ними останнє деся- 
тиліття почали використовувати лапароскопічні хірургічні втручання.

Враховуючи вищезазначене, можна стверджувати, що лапароскопічні оперативні втручання при раку шлунка $є$ актуальною темою сьогодення.

Meта: описово-порівняльна характеристика лапароскопічних анастомозів при: дистальних резекціях шлунка; проксимальних резекціях шлунка; гастректомії.

Об'єкт і методи. Об'єктом дослідження стали: дистальні резекції шлунка з відновленням неперервності шлунковокишкового тракту (ШКТ) такими способами, як: Більрот I (БІ), Більрот II (БІІ), метод за Ру, дельта-анастомоз; гастректомія з відновленням неперервності ШКТ способом циркулярного та лінійного степлера; проксимальні резекції шлунка з відновленням неперервності ШКТ за Ру.

Результати. При дистальних резекціях шлунка з відновленням неперервності ШКТ способом БІ, БІІ отримано такі результати: загальний відсоток ускладнень при БІ $-11,4 \%$, БІІ - 16,9\%; кровотечі при БІ - 1,4\%, БІІ - 1,0\%; неспроможність кукси дванадцятипалої кишки при БІ - 0\%, БІІ $0,2 \%$; неспроможність анастомозів при БІ $-0,2 \%$, БІІ $-0,3 \%$; стриктури при БІ - 0,5\%, БІІ - 1,3\%. При порівнянні способів БІ і методу за Ру відмічали такі симптоми: печія при БІ - 37\%, Ру $-7 \%$; діарея при БІ $-18 \%$, Ру - 8\%; запор при БІ - 9\%, Ру $-11 \%$; демпінг-синдром при БІ - 9\%, Ру - 7\%; кровотечі при БІ $-1,4 \%$, Ру - 0\%; стриктури БІ $-0,5 \%$, Ру $-1,1 \%$.

При гастректомії відновлення неперервності ШКТ за способами циркулярного степлера (одиночного (ОС) та подвійного/напівподвійного (П/НПС) та лінійного степлера отримано такі дані стосовно стриктур після анастомозування: у роботі Choi et al. (2015): ОС $-0 \%, \Pi / Н \Pi C-21,7 \%$; Amisaki et al. (2015): OC $-0 \%, \Pi / \mathrm{H \Pi C}-44,4 \%$; Kosuga et al. (2015): OC $6,2 \%$, П/НПС - $18,3 \%$.

При виконанні проксимальної резекції шлунка відновлення неперервності ШКТ за методом Ру дало такі результати: печія $-12,5 \%$, дисфагія $-12,5 \%$, регургітація $-0 \%$, демпінгсиндром $-12,5 \%$, стенозування $-0 \%$.

Висновки. Дистальна резекція шлунка: БІ - більш фізіологічний; БІІ - менше напруження на анастомоз, технічно простіший; за методом Ру - нижчий ризик рефлюксу жовчі; при пілорозберігаючій операції можливе виконання інтракорпорального дельта-анастомозу.

При гастректоміях відновлення неперервності ШКТ за методом Ру - стандарт операцій.

При проксимальних резекціях основна проблема - рефлюксна хвороба.

Профілактичні операції для носіїв мутацій генів спадкового раку грудної залози: світова практика та власний досвід

І.М. Мотузюк ${ }^{1}$, О.І. Сидориук', Н.В. Ковтун ${ }^{2,3}$, С.В. Костюченко ${ }^{1}$ ${ }^{1}$ Національний медичний університет імені О.О. Богомольия, Київ, Україна

${ }^{2}$ Chiltern Clinical Research Ukraine LLC, Київ, Україна

Київський національний університет ім. Тараса Шевченка, Київ, Україна

Bcmyn. Профілактичні операції для носіїв мутацій генів спадкового раку грудної залози (РГЗ), серед яких найбільш частими є BRCA1/2 мутації, широко використовуються у всьому світі. Як відомо, ВRCA1/2 мутації підвищують ризик виникнення РГЗ до 85\%, раку яєчника - до 65\% (BRCA1) i 23\% (BRCA2), а також пухлин низки інших локалізацій. Дискутуються питання доцільності та користі профілактичної хірургічної тактики для таких хворих.

Meта: дослідити ефективність виконання профілактичних операцій для носіїв мутацій генів спадкового РГЗ у світовій практиці та узагальнити власний досвід 3 цього питання.

об'єкт i методи. Виконано огляд літератури з ефективності профілактичних операцій (профілактична білатеральна мастектомія (ПБМ), профілактична контралатеральна мастек- томія (ПКМ), профілактична білатеральна сальпінгоофоректомія (ПБСО)) щодо наступних питань: 1) зниження ризику виникнення РГЗ; 2) зниження смертності від усіх причин; 3) зниження смертності, пов'язаної з РГЗ. Оцінено тенденції за власними спостереженнями в Україні.

Результати. Для здорових носіїв BRCA1/2 мутацій ПБСО знижує: 1) ризик РГЗ на 45\% (p<0,05); 2) смертність від усіх причин на $65 \%(\mathrm{p}<0,05) ; 3)$ для смертності, пов'язаної з РГЗ, достовірність не доведено ( $\mathrm{p}>0,05)$.

Для хворих на РГЗ носіїв BRCA1/2 мутацій ПБСО достовірно знижує: 1) смертність від усіх причин на $57 \%(\mathrm{p}<0,05)$; 2) смертність, пов'язану з РГЗ, на 66\% $(\mathrm{p}<0,05)$.

Для здорових носіїв BRCA1/2 мутацій ПБМ достовірно знижує ризик РГЗ на 90\% ( $<0,05)$, однак не доведено достовірність щодо зниження смертності від усіх причин та пов'язаної з РГЗ ( $>>0,05)$.

Для хворих на односторонній РГЗ носіїв BRCA1/2 мутацій ПКМ достовірно знижує ризик контралатерального РГЗ на 93\% (p<0,05), смертність від усіх причин на 49\% (p<0,05), смертність, пов'язану з РГЗ, на $48 \%(\mathrm{p}<0,05)$ для періоду спостереження 20 років. ПКМ з ПБСО разом достовірно знижують смертність від усіх причин на 85,5\% (p<0,05).

Через малу кількість пацієнтів та необхідність тривалого спостереження на сьогодні неможливо оцінити зазначені вище показники в Україні. Однак використання світових даних під час консультування схиляє більшість пацієнтів до обрання профілактичних тактик. Так, у Нью-Джерсі (США) кількість ПКМ поступово зростала (з 3,72\% у 2004 р. до 10,82\% у 2014 р.), і схожа тенденція спостерігається, за нашими даними, впродовж останніх років в Україні. Поряд з потенційною користю в аспекті зниження смертності важливим факторами для багатьох пацієнтів $є$ шанс уникнути повторного лікування та можливість знизити онкологічну стурбованість.

Висновки. Кожен пацієнт повинен отримувати повну інформацію про стан свого здоров'я, генетичні зміни та пов'язані з ними ризики, а також про переваги, недоліки та обмеження профілактичних заходів, у тому числі хірургічних. Пацієнт має право обирати найбільш правильний для себе варіант лікування, враховуючи надану лікарем інформацію та власні переконання. Доцільність виконання профілактичної операції $€$ командним рішенням лікаря і пацієнта після його повного інформування.

Fast-track surgery у хворих на рак грудної залози при виконанні онкопластичних і реконструктивних операцій

I.М. Мотузюк, О.І. Сидорчук, П.Л. Понятовський, Е.В. Костюченко Національний медичний університет ім. О.О. Богомольия, Київ, Україна

$\boldsymbol{B} \boldsymbol{c m y n}$. Виконання онкопластичних та одномоментних реконструктивних оперативних втручань у хворих на рак грудної залози (РГЗ) підвищує ризик післяопераційних ускладнень, збільшення термінів перебування пацієнтів у стаціонарі, відтермінування ад’ювантного лікування у порівнянні зі стандартними хірургічними операціями. Розв'язанням наведених проблем стало розроблення та впровадження програми хірургії швидкого відновлення Fast-track surgery (FTS).

Mema: оцінити доцільність та покращити результати лікування хворих на РГЗ шляхом використання мультимодальної програми FTS при виконанні одномоментних онкопластичних та реконструктивних операцій.

Об'єкт і методи. У дослідження залучено 749 хворих на РГЗ T1-4N0-3М0 віком від 18 до 70 років, загальний стан яких за шкалою ECOG $\leqslant 2$. Основну групу становили 253 хворих на РГЗ, в якій було використано концепцію FTS, контрольну 496 пацієнток без використання FTS, які лікувалися з грудня 2010 р. по грудень 2014 р.

Результати. Серед 253 пацієнток основної групи середній

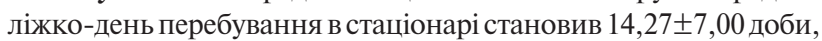
а в контрольній групі серед 496 пацієнток $-20,11 \pm 7,70$ доби 
$(\mathrm{p}<0,001)$. Термін перебування пацієнток у стаціонарі в основній групі був меншим на 8 днів порівняно 3 контрольною групою. Середній ліжко-день без проведення ад’ювантної хіміотерапії (AXT) становив 16,4 доби, а при виконанні АХT $20,1$ доби ( $<00,001)$. Різниця між ліжко-днем з АХТ та без AXT була у 2,7 раза меншою в FTS групі проти групи контролю.

Висновки. Наведені дослідження дозволяють рекомендувати концепцію FTS для впровадження в практику спеціалізованих відділень, оскільки програма FTS довела свою ефективність в хірургії РГЗ, у тому числі для онкопластичних та реконструктивних операцій, що забезпечить меншу тривалість перебування хворих в стаціонарі, зменшення післяопераційних ускладнень та швидше відновлення після операції.

Клінічні дослідження у пацієнтів із меланомою на теренах пострадянського простору та в Західній Європі

В.В. Остафійчук, М.М. Кукушкіна, С.І. Коровін Національний інститут раку, Київ, Україна

об'єкт і методи. Нами було оброблено масив даних клінічних досліджень https://clinicaltrials.gov/, які проводилися в 2009-2019 pр. у 30 європейських країнах (10 із яких в Західній Європі та $20-$ у Східній). Вивчено клінічні випробування за фазами, типом терапії, типом меланоми, стадією захворювання та статусом набору.

Результати. Більшість клінічних випробувань з вивчення меланоми проведено в Західній Європі (720/869); середня кількість випробувань на країну сягала 72, коливалася від 30 (Данія, Швейцарія) до 131 (Франція). У Східній Європі середня кількість випробувань на країну становила 8,4 , варіювалася від 0 (Чорногорія, Молдова) до 44 (Польща); 62,1\% випробувань - це III фаза. Відносна кількість досліджень меланоми шкіри в Західній та Східній Європі зіставна (92,5 і 94,7\%), але кількість досліджень для увеальної і слизової меланоми у Західній Європі більша, ніж у Східній (7,4\% проти 3,6\% і 1,0\% проти 0,6\%). Для I-II, III, IIIC (нерезектабельна)/IV стадій меланоми було проведено 4,4; 8,2 і 87,6\% випробувань в Західній Європі та 4,7; 11,8 та 87,6\% - у Східній відповідно. Цільова терапія, імунотерапія та комбіноване лікування були вивчені в 38,$3 ; 52,6$ та 4,7\% випробуваннях у Західній Європі та 45,6 ; 44,4 та 8,3\% - у Східній відповідно. Сьогодні лише у 24,3\% випробувань продовжується набір пацієнтів у Східній Європі та у $31,4 \%$ - у Західній.

Усі західноєвропейські країни проводять клінічні випробування для пацієнтів з меланомою, починаючи з 6 (Австрія) до 44 (Франція), тоді як наразі у 45\% країн Східної Європи не проходять клінічні випробування.

\section{Клінічні та морфологічні особливості пухлин зовнішніх статевих органів у жінок}

\section{о.о. Самохвалова}

Національний інститут раку, Київ, Україна

Bcmyn. Рак зовнішніх статевих органів (3СО) становить до $8,0 \%$ загального показника захворюваності на злоякісні пухлини жіночих статевих органів і займає четверте місце після раку шийки, тіла матки та яєчника.

Однією із проблем патології є пізнє звернення в зв'язку малосимптомним перебігом захворювання в ранній стадії. Як наслідок, до 60,0\% жінок звертаються по медичну допомогу із III-IV стадією захворювання, що є вкрай негативним для прогнозу та ефективного лікування.

Mета: провести аналіз вікових особливостей пацієнток з раком 3СО, локалізації пухлин та стадії захворювання.

Об'єкт і методи. У дослідження включено 131 жінку з ра-

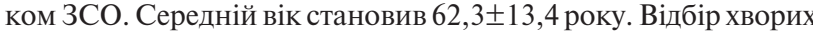
для включення у дослідження проводився за такими критеріями: 1) вік - від 18 до 70 років; 2) письмова згода на участь в дослідженні; 3) морфологічна ідентифікація раку вульви.

Критерії виключення: 1) гострі інфекційні захворювання; 2) наявність пухлин іншої локалізації; 3) наявність клінічно значущої кардіальної патології в анамнезі; 4) наявність ВІЛінфекції, вірусних гепатитів В і C; 5) періоди вагітності та лактації; 6) участь у будь-якому іншому дослідженні впродовж останнього місяця.

Результати. За аналізом вікових особливостей пацієнток, що звернулися з приводу раку ЗСО, встановлено, що пацієнтки віком до 40 років становили 7,6\% обстежених (10 осіб), 41-50 років - 12,2\% (16 осіб), 51-60 років - 17,5\% (23 особи), $61-70$ років - 29,8\% (39 осіб), 71 рік та більше $-32,8 \%$ (43 особи). Таким чином, відмічено особливість переважання раку ЗСО серед пацієнток, що звернулися в Національний інститут раку, - вік 60-70 та $>70$ років.

На рак вульви припала найбільша частка пацієнток у дослідженні, що становило 85 клінічних випадків $(64,9 \%)$, пухлини великих статевих губ виявлено у 20 жінок (15,3\%), малих статевих губ - у $9(6,9 \%)$, поєднане ураження - у 4 (3,0\%), первинну локалізацію пухлини в бартоліновій залозі відмічено у 4 пацієнток (3,0\%), ураження клітора - у $6(4,6 \%)$, задньої спайки - у 1 пацієнтки $(0,8 \%)$, тотальне ураження - у 2 хворих $(1,5 \%)$. За гістологічними особливостями більша частина пухлин була представлена плоскоклітинним раком $-105(80,2 \%)$, із них зроговілим -78 випадків $(59,6 \%)$, плоскоклітинним незроговілим $-25(19,1 \%)$ та базальноклітинним $-2(1,5 \%)$.

Висновки. У статті наведено результати 3-річного проспективного спостереження у жінок, що звернулися з пухлинами ЗСО в Національний інститут раку з 2016 по 2018 р.

Встановлено, що віковими особливостями пацієнток з раком $3 \mathrm{CO} є$ приріст захворюваності після 50 років $(17,5 \%)$. Максимальний пік захворюваності встановлено $(\mathrm{p}<0,05)$ у період $61-70$ років $(29,8 \%)$ та старше 71 року $(32,8 \%)$.

Можливості дистанційної променевої терапії у лікуванні масталгії, що індукована прийомом антиандрогенів, у хворих на рак передміхурової залози

\section{О.В. Сафронова}

КЛ «Феофанія» ДУС, Всеукраїнський центр радіохірургії, Київ, Україна

Bcmyn. Одним із методів лікування раку передміхурової залози (РПЗ) є медична кастрація із призначенням агоністів лютеїнізуючого гормону рилізинг-гормону та антиандрогенів. Гінекомастія та/або мастодинія є частим побічним ефектом антиандрогенної терапії РПЗ і може погіршувати якість життя пацієнтів.

Mema: оцінити можливості дистанційної променевої терапії (ДПТ) у лікуванні гінекомастії з масталгічним синдромом у хворих на РПЗ, які приймають андрогенну деприваційну терапію.

Об’єкт іметоди. У відділенні променевої терапії КЛ «Феофанія» ДУС проведено лікування масталгічного синдрому у 15 хворих на РП3, які перебували на тривалій терапії антиандрогенами. Лікування проводилося на лінійному прискорювачі із використанням енергії електронів разовою вогнищевою дозою 6,0 Гр до підведення сумарної вогнищевої дози 12,0 Гр на ареолярну ділянку з відступом 3,0 см. У всіх пацієнтів застосовували однаковий алгоритм лікувального процесу (виготовлення свинцевого блоку для формування поля опромінення, передпроменева підготовка на комп'ютерному томографі, оконтурювання з включенням в обсяг опромінення патологічної залозистої тканини грудної залози, індивідуальне планування та лікування). Критеріями ефективного лікування були: суб'єктивне зменшення больового відчуття в ареолярній ділянці, об'єктивне пом'якшення грудної залози. Для додаткового контролю не раніше ніж через 6 міс після курсу ДПТ можливо проведення комп'ютерної томографії (KT) грудної клітки з оцінкою стану грудних залоз.

Результати. За результатами нашого дослідження у 100,0\% пацієнтів відбувалося зменшення чи зникнення явищ масталгічного синдрому, що було головним критерієм 
якості терапії. Прояви гінекомастії зменшилися у 40,0\% пацієнтів. За результатами контрольної КТ не виявлено жодного негативного впливу на легені при терміні спостереження 12 міс.

Висновки. Мастодинію, індуковану прийомом антиандрогенів, можна ефективно лікувати радіотерапією без відповідних побічних ефектів. Ці результати свідчать про перспективу призначення ДПТ на початку прийому гормонотерапії для профілактики виникнення гінекомастіі.

\section{Інноваційний підхід у верифікації та лікуванні гепатоцелюлярної карциноми в експерименті}

\section{О.В. Телегузова}

Вінницький національний медичний університет ім. М.І. Пирогова, Україна

Bcmyn. Гепатоцелюлярна карцинома (ГЦК) становить понад $90 \%$ усіх первинних пухлин печінки та визнається світовою спільнотою як важлива глобальна проблема. ГЦК $\epsilon$ високоактивною пухлиною, стійкою до традиційної хіміота променевої терапії, що зумовлює поганий прогноз щодо наслідків лікування та виживаності. Для лікування ГЦК розроблено різні протипухлинні препарати, однак вони здатні продовжити тривалість життя приблизно на 3 міс. При цьому незрозумілими залишаються механізм лізису пухлини та фактори, які впливають на нього.

Meта: дослідити вплив локорегіонарної онколітичної віротерапії Herpes simplex virus (HSV-1 T-01) у поєднанні з емболізацією розчинними мікросферами на ортотопічну ГЦК у щурів та верифікувати специфічні механізми лізису пухлини.

Об’єкт іметоди. Дослідження проведено на 50 самцях щурів лінії Буффало з мультифокальними ортотопічними вузлами ГЦК. Група А (контрольна) - введення 0,9\% фізіологічного розчину; група В - трансартеріальна хіміоемболізація печінкової артерії емболами Pharma Cept EmboCept з сорафенібом та простим вірусом герпесу людини; група С - емболізація печінкової артерії просоченими вірусом герпесу емболами Pharma Cept EmboCept; група D - лапароскопічна операція з інтратуморальним введенням хіміотерапії. Після проведення необхідного обсягу лікування виконано гістологічний та імуногістохімічний аналіз результатів, оцінка відповіді пухлини здійснена за критеріями MRECIST.

Результати. Значні зміни індексу апоптозу спостерігали в усіх групах, де застосовувалася віротерапія. Однак найвищим індекс апоптозу був у групі В у порівнянні з іншими трьома групами $(\mathrm{p}<0,05)$.

Висновки. Онколітична віротерапія показала перспективні результати в лікуванні ГЦК, однак відзначається посилення ефекту шляхом комбінованої терапії. У дослідженні продемонстровано позитивні кінцеві результати при лікуванні ГЦК. Таким чином, комбінована онколітична терапія з блокуванням імунної контрольної точки підвищує швидкість досягнення максимального ефекту лікування і $є$ однією з найбільш дієвих методик лікування ГЦК на сьогодні.

\section{Оптимізація судинного доступу у хворих, що отримують системну хіміотерапію}

\section{I.А. Тіунова, А.Р. Тарковський, Л.А. Сивак}

Національний інститут раку, Київ, Україна

Bcmyn. 3 огляду на те що сучасна системна хіміотерапія може супроводжуватися випадковим потраплянням лікарських засобів внутрішньошкірно або підшкірно в місці судинного доступу з розвитком екстравазацій, інфікування, тромбозу, лікування пацієнтів з онкологічними захворювання неможливе без створення адекватного судинного доступу, що забезпечить найбільш ефективну та безпечну системну терапію.
Метою роботи було підвищення безпеки хіміотерапії та якості життя пацієнтів з онкологічними захворюваннями шляхом вибору найбільш оптимального судинного доступу.

Об'єкт і методи. Проаналізовано 540 джерел літератури за допомогою пошукових систем Ovid Medline, EMBASE and Cochrane Central Register of Controlled Trials з 1946 по лютий 2019 р. Статистичну обробку матеріалу проведено за допомогою програми Statistica 10.

Результати. Дані дослідження свідчать, що з 1946 по 2019 р. не було проведено жодного рандомізованого дослідження щодо вибору судинного доступу у пацієнтів, які отримують хіміотерапію. Результати восьми ретроспективних та шести проспективних досліджень показали, що використання внутрішньовенних або підключичних катетерів для проведення хіміотерапії призводило до більшої кількості ускладнень, ніж застосування портів: інфікування - у $6 \%$ проти 2,1\% пацієнтів; екстравазації - у 2\% проти $0,4 \%$ пацієнтів. Частота виникнення тромбозу в групі пацієнтів, які отримали хіміотерапію за допомогою підключичного катетера, становила $8,9 \%$, а в групі пацієнтів з використанням портів лише $0,4 \%$. Якість життя була кращою у пацієнтів зі встановленим портом, проте суттєво не відрізнялася між двома групами.

Висновки. Проведення хіміотерапії з використанням портів асоціюється з меншим ризиком виникнення ускладнень порівняно із застосуванням внутрішньовенних та підключичних катетерів. Потрібно проводити рандомізовані дослідження для отримання більш достовірних даних.

\section{Закриття післяопераційних дефектів дистальних відділів кінцівок після видалення пухлин шкіри}

\section{Д.О. Чорненький, М.М. Кукушкіна, С.І. Коровін, \\ В.В. Остафійчук, С.А. Дєдков}

Національний інститут раку, Київ, Україна

Bcmyn. Закриття післяопераційних дефектів дистальних відділів кінцівок після видалення пухлин шкіри становить певні труднощі, зумовлені незначною еластичністю шкіри та невеликою кількістю підшкірної клітковини на цих ділянках кінцівок. Одним із можливих шляхів закриття післяопераційних дефектів може бути використання так званого key-stone, або острівцевого, клаптя.

Mema: оцінити безпосередні хірургічні та відстрочені естетичні результати закриття післяопераційних дефектів дистальних відділів кінцівок за допомогою key-stone клаптів.

Об'єкт і методи. У дослідження включено 12 хворих (7 жінок, 5 чоловіків, середній вік $-53,5 \pm 4,8$ року), яким проведено операції у відділенні пухлин шкіри та м'яких тканин з січня 2018 р. по лютий 2019 р. $з$ приводу пухлин шкіри (6 - меланома, 6 - базально-клітинний рак шкіри), шо локалізувалися на шкірі передпліччя (3 випадки) або гомілки (9 випадків). Оперативне втручання включало широке висічення пухлини шкіри з відступом від краю утворення від 0,5 до 1,5 см залежно від гістологічного типу пухлини та закриття ранового дефекту key-stone клаптем. У 4 пацієнтів для зменшення натягнення клаптя виконували його перфорацію у вигляді множинних насічок на шкірі.

Результати. У всіх 12 (100\%) хворих рани зажили первинним натягом. Зважаючи на натягнення шкіри, шви знімали на $18-21-ш у$ добу після операції. У $5(41,6 \%)$ пацієнтів 3 локалізацією пухлини на шкірі нижньої третини гомілки відзначалася лімфорея тривалістю 5-12 днів. Естетичні результати після повного заживлення ран задовільні як з погляду хірургів, так і на думку пацієнтів.

Висновки. Закриття післяопераційних дефектів дистальних відділів кінцівок після видалення пухлин шкіри за допомогою key-stone клаптів сприяє заживленню ран первинним натягом та задовільному естетичному результату. У деяких випадках з метою зменшення натягнення шкіри може бути необхідною перфорація клаптів. 